\title{
DR1 wt Allele
}

National Cancer Institute

\section{Source}

National Cancer Institute. DR1 wt Allele. NCI Thesaurus. Code C53101.

Human DR1 wild-type allele is located in the vicinity of $1 \mathrm{p} 22.1$ and is approximately $17 \mathrm{~kb}$ in length. This allele, which encodes TATA-binding protein-associated phosphoprotein, is involved in the suppression of transcription. 